Original Research Paper

\title{
Inculcating Human Values among School Students through Effective Teaching
}

\author{
Bhim Chandra Mondal \\ Nikhil Banga Sikshan Mahavidyalaya, Bishnupur, Dist-Bankura, 722122, West Bengal, India
}

Article history

Received: 07-12-2014

Revised: 26-01-2017

Accepted: 12-06-2017

Email: bhimsttc@gmail.com

\begin{abstract}
Education is an essential process for inculcating values to enhance the learner in such a way so that they can lead a life that is gratifying to the individual in accordance with the cultivated values as well as with the ideals of the society. Values are those tools which help them for betterment of the quality of life. The value forms the basics of character formation and the development of personality. The values that spring from within or the core of the heart, like love, humanity, compassion, kindness, appreciation, patience, etc. lay the foundation for the external practiced values like fairness, discipline, punctuality and faith. It is important to recall that values are priceless, while valuables are priced. It is difficult to create value without the processes and orientations of other parts of the school system. If values are integrated with the educational system as a whole, the better will be the result of imparting values. Through quality teaching teacher can transfer true knowledge which helps to raise values among the students.
\end{abstract}

Keywords: Human Value, Education, Students, Teaching Strategy, Inculcation

\section{Introduction}

In this ambitious world, man seems to have compromised with his values, integrity and character, to earn more and more wealth. For this, it is noticed the excessive corruption, unlawful activities, brutal behavior and immoral consumption, which is slowly breaking the backbone of our society, nation and the world. Therefore, there is an urgent need to impart value based educational system dealing especially with human values and to do so reorganization of our educational system is essential. A child's mind is soft clay which can be molded to any desired shape. Thus, the early stage is the correct time to impart value inculcation into our system so that the right impressions formed in the child's mind will guide him throughout his life based on noble principles.

It is well known that teaching positive values like respect, honesty, compassion, care, humility and responsibility etc. improves the quality of education in schools (Hasan et al., 2014). A values-oriented school seeks to enhance an educational philosophy based on valuing self and others, through the consideration of a values vocabulary as the basis of good educational practice.

\section{What is Value}

Values neither can be defined nor be measured. Education is normative enterprise where value plays vital role for determining the quality of life. It can be defined as the objectives and states of affairs that can be designed by the individual. Value is something which pervades everything. It determines the meaning of world as a whole as well as the meaning of every person, every action, even the smallest change introduced into the world by an agent has a value (Bala, 2016).

Values are those principles, which assists us for the betterment of the quality of life. It codifies the do's and don'ts of behavior. They form the basics of character formation and development of personality. The values that arises from within or the core of the heart, like love, compassion, appreciation, empathy, patience, etc. lay the basis for the external practiced values like honesty, discipline, regularity and loyalty. It is important to recall that values are priceless, while valuables are priced (Goel and Goel, 2008).

Value is also defined as important and lasting beliefs or ideals shared by the members of a society about what is right or wrong and desirable or undesirable. Behavior 
and attitude are highly influenced by cultural values which serve as broad guidelines throughout the life. According to Makiguchi, a Japanese Philosopher "value arises from the interaction between humans and their surroundings and it is only in this sense that value can be created; truth cannot then be a component core of value" (Bethel, 1973; Sharma, 1998, p. 11).

Values regulate and guide human behavior and action in our daily life. They are embedded in every word we select and speak, what we wear, ways in which we communicate, our perceptions and interpretation of others response in what we are say. They are constructed on the basis of interests, choices, needs, desires and preferences. These comprise the nuclei of value formation.

Values have a selective or directional quality. When preferences acquire certain definiteness, intensity and stability, these become the criteria for judgments, choices, action and grounds for decision-making in behavior. Thus, value is considered to be an enduring belief upon which human beings act by preferences. Values involve the processes of thinking, knowing/understanding feelings and action. These involve feelings i.e., strong liking for something, feeling deeply about the things one values and so on.

\section{Why Value Creation is Important}

A most important reason for value orientation is the fact that the current model of education contributes to the disproportionate development of students. This model of education puts exclusive focus on cognitive domain without giving focus on the affective domain which results alienation between head and heart. Students are nurtured in a spirit of enormous competition and are trained right from the beginning to relate to aggressive competition and facts detached from contexts. The individualistic idea of excellence is promoted at the cost of emotional and relational skills. Learners hardly realize why they are in school, why they are studying different subjects and how their schooling will be helpful to them. They hardly know how they should live their lives, commit themselves to the welfare of the country, care for the environment and other social and moral issues. They are not clear what they want to be after completion of their schooling (Clement, 2010). The problem of declining values is multi dimensional arising out of combination of major social forces such as globalization, actualization, consumerism, commercialization of education, threats to humanity due to climatic changes, degradation of environment, violence and terrorism. These lead to insecurities, individualistic life styles, acceleration of desires, misuse of science and technology, pessimisms, sense of alienation and other negative consequences (NCERT, 2000).
The current resurgence of interest in education as a powerful means to impart values among students is also due to the fast deterioration of values in our country. Despite considerable development made, our society is full of conflicts, corruption and violence as a result of which distortion of value system occurs in our society. Wherever we look, we find falsehood and corruption. Majority of the people are interested in their own families and not interested in fulfilling our responsibilities to society. Although erosion of values existed throughout the history of human existence and is shared by all cultures but current degeneration of values has become a matter of great concern in our country (NCERT, 2000).

\section{How to Create Value}

Values creation is the process through which individual transmit values to others (Powney et al., 1995). It may be an activity that take place in any organization during which people are assisted by others, who may be in a position of authority or are more experienced, to make explicit those values underlying their own behavior, to assess the effectiveness of these values and associated behavior for their own and others' long term well-being and to reflect on and acquire other values and behavior which they accept as being more effective for long term benefit of self and others (Hasan et al., 2014).

Impartment of values takes place during the process of socialization that always occurs in a context. As socio-cultural milieu differs from one society to other, there is easily created various space for value orientation. There are different layers of contexts according to the ecological perspective. The smallest of the context in which the child lives and moves is the immediate family, school teachers and mates and the neighborhood, play area etc. Another layer of context is the direct involvement of individuals affecting such as interaction of parent with neighbors etc. Still the wider context relates to the larger community in which the child lives. Though the child might not have direct contact but the different layers of systems affect the child's development and socialization. Every layer of context interacts making a highly complex context in which the child grows up. As people affect a child so the child has an influence on them. Nothing ever remains static. The context also changes as the child grows. It influences the child's attitudes, behavior, values etc. Values are learnt as we learn habits from the environment. Learning of values takes place quite early in life by the word of mouth or simple commands from parents and other adults at home. In early years of life, prohibitions and parent identifications are the source of values. 
At early stage children rapidly grasp which behavior are approved and which ones are not, which are likely to bring rewards and which might lead to punishment. They attach notions of good or bad, right and wrong to different acts and behaviors. Reward and punishment, approval and disapproval act as positive or negative reinforcers. The nature of association positive or negative and its frequency is thus important to form a value. When the end result leads to appreciation, positive association forms whereas negative associations are formed due to opposite end result. The person tends to repeat the act or behavior which serves the desired end. When these are repeated under favorable conditions of reinforcement, they form into habits and get deeply ingrained as strong behavioral tendencies. Initially, there may not be any conceptualization but later such learning may be transferred from one particular situation to another. When students are made to judge themselves the worth of prioritized activity, situation or an idea by independent appraisal and reflection, the internalization of values takes place (Clement, 2010).

The idea of value creation gives emphasis on the autonomous capacities of learners. Children arrive at school already possessing experience, knowledge and a capacity to learn. Value-creating pedagogy engaged students in learning to create wisdom from knowledge in order to derive meaningful value in and from any situation (Carr, 2010). That is why we have to foster students' creativity and ability to consciously apply learned knowledge in ways that generated personal benefit and social good. Such a value-implantation life was committed, contributive and, thereby, fundamentally happy.

\section{Strategies for Value Creation}

Constructive strategy laid emphasis on learners instead of the teachers. This strategy for value creation, grounded on the philosophy that children construct their own theories of how the world works, though their minds are less developed than those of educated adults. This approach meant that not only were values taught explicitly and systematically, but that an environment was constructed that reflected and incorporated the values being proffered. Not the least of the structure is to be found in the conscious modeling of values by staff themselves, both in their office relationships and their relationships with students and their parents.

Implanting values is different from teaching any other school subject (Hasan et al., 2014). Teaching strategy must emphasis on how to think about something, to reflect, critically evaluate, appreciate one's own values and those of others, develop better communication, better decision-making so that the concepts ultimately find their ways into behaviors and actions. It is not only confined to the cognitive level but also covers the affective and behavioral levels. Attitudes, values and skills cannot be developed neither by forcing students to memorize nor by impositions. Provisions must be provided to internalize such attitudes and values, which can be sustained in the long run. The learner can only then take a conscious decision of practicing values, consciously and responsibly. The pedagogy thus shifted from the conventional model to an experiential or participatory model. This model assumes that it is not what to teach but how to teaches, that is important and that is the essence of education for value. In the absence of this, value creation could become just another duty, proclaimed to be done by schools, whereas it has to be the adoption of different ways of interacting, relating and being with students and using ways of teaching and learning to provide concrete learning experience (NCERT, 2000).

\section{Some General Strategies}

Attitudes and values are best imbibed through few experiential and participatory modes of learning. Due to complexity of the process of values development and the broad range of values to be nurtured, few experiential and reflective strategies as follows to be integrated with curricular and co-curricular activities in school.

\section{Meditation}

Sitting quietly for a few minutes with the attention turned inwards towards a peace-filled realm of limitless proportions is good for health. Silent sitting also helpful in improving self confidence (Singh and Kaur, 2008), enhancing positive emotions, ability to get along with others and experiencing calmness and inspiration. Strengthening of self, consolidating information received, concentration and assimilation, clear thinking, memory and retaining are developed properly through meditation. So, teacher should spare two minutes before beginning of the lesson for meditation in every subject which may serves as a warm-up exercise especially for younger children.

\section{Visual Perception}

Visual perception is the ability to interpret the surrounding environment by processing different information. Symbols, images, drawings, charts, posters, graphs and auditory and kinesthetic experiences are concrete objects which are helpful in grasping the fact in comparison to verbal mode of instruction. It is also powerful tools for communication of attitudes and values and forming imagery at the early primary years of schooling.

\section{Role Playing}

Role-playing refers to the changing of individual's behavior to assume a role, either unconsciously to fill a 
social role, or consciously to act out an adopted role. In role playing emphasis is not given on the acting capabilities but on the projection of values and analysis of the same (Kotaiah, 2014). This analysis brings out why a person should or should not accept the value in question and act on all occasions upholding the same. Role playing helps in better understanding and reinforcing the importance of values. It can be conducted according to the age groups. The whole process of role playing involves (a) acting out the story (b) depicting certain values (c) miming (d) reporting involving the processes of Seeing, Judging, Acting and Internalizing. Reflection through which of attitude change and growth in values takes places in reflecting is the crucial part of role playing. The art of conducting role plays and using them particularly for younger students requires orientation and practice (NCERT, 2000).

\section{Story Telling}

Interactive art of using words and actions to reveal the elements and images of a story that enhanced the power of imagination of the learner is referred as storytelling which leaves a perennial impression on the minds of children (Dash, 2015). Educators used story telling techniques through meaningful narratives which are rooted in ordinary life setting to promote understanding and insight to human behavior to influence practice. But the new understanding of how the mind works and how brain stores propositions and episodes in a different way, has over scored the traditional ways of communicating knowledge. Authenticate and persuasive tales, rooted in real world, to be communicated in such a way so that it is comprehensible and appealing to students for understanding values. Stories and examples of the lives of great personalities can include the emphasis that greatness achieved is not sudden but through patience, perseverance and practice. The emphasis has to be on drawing lessons directly and or indirectly appropriate to the age of the students. The active participation of students should be elicited which will give them occasion to reflect on various aspects of the lives of great men and the values they embodied. The study of religious stories highlighting the essentials of all religions would be rewarding as a step towards harmony among religions as basic teachings of all great religions of the world are the same. In order to present the themes relating to unity of faith a lot of ingenuity is required. The fables and parables of any culture must bear some cult knowledge where values are always highlighted. The explanation of such stories by elder persons may be parents or teachers can be most effective particularly in the junior classes. However, at the post elementary stage, students are allowed to study the lives of great religious and spiritual leaders to impart value within them.

\section{Anecdotes}

Anecdotes are the real life experiences which portray genuine human feelings and expressions. Anecdotes such as stories present a variety of perspectives on certain life situations, different ways of experience and understand things that are important in one's life. This anecdote may create a lasting impression on a student's mind touched the core of heart and may have brought about a shift in the course of the life. It is very useful for communication with the matter in a friendly manner, understanding the matter by making abstract concrete and easily comprehensible; motivating and inspiring people to reflect, think deeply about the situations. These also help in identifying with those living by the values; providing meaningful understanding of the varied situations; learning about different perspectives and choices and skills in dealing with conflicts, crisis situations, events and day to day situations; evoking emotions and feelings. The anecdotes depicting conflicts, dilemmas, human acts and approaches to dealing with different life situations, drawn from home, school, classroom contexts portraying values important for students can be integrated with curricular areas.

\section{Group Singing}

Lyric of the meaning song generally remains in the consciousness for a long time. Singing in a choir provides an immediate and tangible manifestation of the power and the joy of co-operation. It signifies the unity, towards a common purpose or goal, co-operation, discipline, self-restraint and the spirit of accommodation. The serenity of a song mentally prepares one to concentrate on the better human qualities like love, integrity and forgiveness which are gateway to value. So group singing at morning assembly should be sang to promote values among the students.

\section{Group Works}

Many values can be learned concurrently through group work. Improvement of fundamental values of love, tolerance, cooperation, peaceful co-existence, mutual respect is important. By working in groups, students learn the value of each other's sincere efforts, joy of doing one's best for the good of the whole group (Rai, 2014). Group activity includes role playing, games, group discussion, group projects etc. could be used in teaching of subjects as well. Such activities are to be organized in such a way so that value can be inculcated value among the learners.

\section{Discussion}

Discussion can serve as a means for other students to deliberate on certain social, political and moral issues where values, as such, are not the focus of 
discussion in their own right but are underlying the topic. In present era, people are faced with complex situations, dilemmas and issues related to social justice, human rights and freedom, environment, population control, peace and disarmament. It is important to realize that discussions can help students become aware of the variety of ideas and view points, be tolerant to the different views, can help them clarify their own views through the effort of having to get across to others, can help them resolve a dilemma or clarify their values. Often, it may enable students to arrive at an agreement. It makes the student aware that certain issues cannot be resolved to everyone's satisfaction. Any kind of organized discussion should be followed by reflective exercises like what did they learn from the discussion. Identification of value issues suitable for different age groups with potentials for discussion is important.

\section{Value Clarification}

Value clarification is primarily used for problematic situation, with conflicting alternatives or equally competing values. This strategy allows the students to choose one out of the two, reflect on what is chosen and what is valued by the person. It aims at helping students look closely at their ideas, behavior, attitude thereby clarifying themselves what they really value. Imposing one's own ideas or moralizing what the teacher thinks is right or wrong is deliberately avoided.

\section{Reflective Practice}

Reflective practice is a process by which individual think over a practice, consciously analyze the process of decision making and draw on theory and relate it to what to do in practice. If students are given opportunity and space for thinking back of their experiences, they can begin to see what is important, what mistakes are being made by them, where things can be modified and so on. In spite of the over packed school schedules, the school have to decide and prioritize regarding reflective practice. It is worthy to remember that any kind of activity must be followed by reflection on particular experience. Reflection is not enough on its own. What matters is the effect it will have on self. It is often said that action without reflection is just busyness. The real benefit of reflection is the greatest strength of reflective practice to be seen things through new rays.

\section{Conclusion}

We live in a time when our understanding of the role of the quality teaching and the power of values education are collapsing. To impart value among the learners, quality teaching should always be given the prime focus. Now-a-day, it is unfortunate that teaching has become primary concern and values are now secondary. Value implantation among students has potential to refocus the attention of teachers and their systems on the fundamental item of all effective teaching, namely the teacher her or himself, the quality of the teacher's knowledge, content and pedagogy and above all on the teacher's capacity to form the kinds of relationships with students which convey their commitment and care and which become the basis of forming personal character and tomorrow's citizenry. We will dream for better tomorrow when value implantation will be chief goal of education.

\section{Acknowledgment}

The author would like to thank the referee(s) for their suggestions which helped a lot to improve the article.

\section{Ethics}

There are no ethical issues that may arise on the publication of this article.

\section{References}

Bala, M., 2016. A Study of value profiles of secondary students in relation to their self-concept and academic achievement, Ph.D. Dissertation, Maharshi Dayanand University.

Bethel, D.M., 1973. Makiguchi the Value Creator, Revolutionary Japanese Educator and Founder of Soka Gakkai. 1st Edn., Weatherhill, Inc., New York, ISBN-10: 0834800772, pp: 174.

Carr, D., 2010. Personal and Professional Values in Teaching. In: International Research Handbook on Values Education and Student Wellbeing, Lovat, T., R. Toomey and N. Chandra (Eds.), Springer Netherlands, pp: 63-74.

Clement, N., 2010. Student Wellbeing at School: The Actualization of Values in Education. In: International Research Handbook on Values Education and Student Wellbeing, Lovat, T., R. Toomey and N. Clement (Eds.), Springer, Dordrecht, Netherlands, pp: 37-62.

Dash, D., 2015. Effectiveness of story telling approach in inculcating values identified by NCERT among the 6th grade learners of Odisha State. Scholarly Res. J. Interdisciplinary Stud., 3: 2583-2590.

Goel, A. and S.L. Goel, 2008. Human Values: Principles and Practice. 1st Edn., Deep and Deep Publications Pvt. Ltd., New Delhi, ISBN-10: 8184500955,

Hasan, A.A., M.I. Hamzah and M.M. Awang, 2014. Inculcating noble values for pre-service teachers. Int. Educ. Stud., 7: 111-119. 
Kotaiah, V., 2014. Role of the teacher in development of moral values. Int. J. English Lang. Literature Translat. Stud., 1: 70-72.

NCERT, 2000. Education for values in school: A framework. National Council of Educational Research and Training, New Delhi.

Powney, J., M.A. Cullen, U. Schlapp, M. Johnstone and P. Munn, 1995. Understanding Values Education in the Primary School. Reports Express, New York.
Rai, R., 2014. Inculcation of values: A necessity today. Int. J. Educ. Res. Technol., 5: 30-32.

Sharma, N., 1998. Value Creators in Education: Japanese Educator Makiguchi and Mahatma Gandhi and their Relevance for the Indian Education. 1st Edn., Regency Publications, New Delhi, ISBN-10: 8186030603, pp: 136.

Singh, T. and P. Kaur, 2008. Effect of meditation on self confidence of student-teachers in relation to gender and religion. J. Exer. Sci. Physiotherapy, 4: 35-43. 